\title{
Asking for Young Offenders: What is the Fate of Restorative Justice within Nigeria's Discretionary Diversion Policy?
}

\author{
Collins Okoh*
}

\begin{abstract}
The young offenders' justice system in Nigeria represents an area where the law has failed to respond properly to the needs it was designed for. Many empirical studies conducted over 17 years show that young offenders in Nigeria are continuously subjected to the state-sanctioned processes and practices-the formal justice system - which goes against the best interest of the child principle. This is despite the fact that Nigeria has ratified the United Nations Convention on the Rights of the Child and domesticated it through the Child's Rights Act 2003 (CRA). The problem is that the diversion policy framework under the CRA offers discretionary powers to state officials who drive the formal justice system. This allows these officials to choose whether to divert cases and to select which restorative justice mechanisms to divert to at any level of the young offenders' justice system. This paper argues that taking away such discretionary powers can help to improve the treatment of young offenders under the Nigerian criminal justice system. Drawing lessons from New Zealand, this paper suggests, among others, a mandatory diversion policy for a committed practice of juvenile restorative justice in Nigeria.
\end{abstract}

Keywords: Young offenders, restorative justice, diversion policy, CRA, UNCRC, FGC, CYPFA

\footnotetext{
The author is a third year LLB student at Strathmore Law School. He extends his gratitude to Rev. Father Gabriel Ysasi for his unending support and prayers. Special acknowledgement goes to $\mathrm{Mr}$ Arnold Nciko for sharing his pearls of wisdom during this research, and Ms Stephanie Marimba for her research insights. Finally, the author thanks the members of the Strathmore Law Review for their comments that greatly improved the final output of this research idea.
} 


\section{Table of Contents}

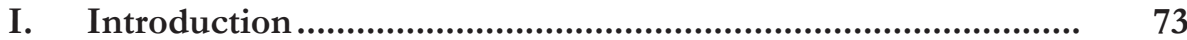

i. Background ................................................................................

ii. Higblighting the problem ....................................................................... $\quad 75$

II. Restorative Justice and the Best Interest of the Child Principle 77

i. Understanding restorative justice ............................................................ $\quad 77$

ii. Some benefits of restorative justice .......................................................... 80

iii. The flaws of the formal justice system ..................................................... 82

III. The International Standards for Restorative Justice Practices . 84

i. $\quad$ The international legal instruments ......................................................... 84

a. The UNCRC ........................................................................ 84

b. The Beijing Rules......................................................................... 85

c. The Tokyo Rules and the Riyadh Guidelines........................... 86

ii. The underperformance of Nigeria .......................................................... 87

IV. Mandatory Diversion Policy in Action: Lessons from

New Zealand...................................................................... 89

i. The legislative measures in New Zealand................................................. $\quad 90$

ii. Mandatory diversion policy for restorative justice in

New Zealand.................................................................................... 91

iii. The role of the court and the synergy between the parallel systems in New Zealand.....................................................................

V. Paving the Way Forward for an Effective Diversion Policy and Juvenile Restorative Justice in Nigeria ................................

VI. Conclusion 


\section{Introduction}

\section{i. Background}

Penal offence by young offenders is a global tragedy that Nigeria continues to face. Nevertheless, as the justice systems are expected to deliver justice, in doing so, they ought to pay due attention to the vulnerable status of young offenders by considering the best interests of the child principle. ${ }^{1}$ This principle is guaranteed in several international law instruments including the United Nations Convention on the Rights of the Child (UNCRC). ${ }^{2}$ It demands that considerable weight must be given to the varying special needs of a child. ${ }^{3}$ The United Nations Committee on the Rights of the Child (CRC) closely links this principle to some rights in the UNCRC like the right to survival and personal development, and the right to participate in the affairs that concern the child and to be heard. ${ }^{4}$

This paper considers the welfare and needs of young offenders-a class of children within the larger beneficiaries of the principle. Generally, some of the needs are the offender's rehabilitation from the effects and underlying causes of the offence, and their reintegration into society. ${ }^{5}$ Probably because of their complexity, law and restorative justice scholars have termed these needs as part of the fulcrum of the restorative justice system. Consequently, the solutions to these needs require innovations that are reached through multidimensional, multi-layered and interdisciplinary approaches.

Although there is no consensus in scholarship on the definition of 'restorative justice' as a concept, these scholars tend to agree on two elements. The first is that restorative justice focuses on the harm done and not the offender. ${ }^{6}$ The second is that to properly actualise restorative justice, reconciliation, rehabilitation,

\footnotetext{
Setyorini EH and Utomo P, 'Restorative justice concept for children conflicting laws in children criminal justice system' Proceedings of the International Conference on Law Reform (INCLAR 2019), Batu City, Indonesia, 24-25 September 2019 (Published 2020), 198.

2 Article 3(1), United Nations Convention on the Rights of the Child, 20 November 1989, 1577 UNTS 3.

3 UN Committee on the Rights of the Child (CRC), General comment No. 14 (2013) on the right of the child to have his or her best interests taken as a primary consideration, 29 May 2013, CRC /C/GC/14, para 80-84.

4 UN Committee on the Rights of the Child (CRC), General comment No. 14 (2013 on the right of the child to bave his or her best interests taken as a primary consideration), 11.

5 Alexinas M, 'Working for better outcomes: An inquiry into the Rehabilitation and Reintegration of ex-offenders through integration in the labour market as a part of the Criminal Justice process' Published LLM Thesis, University of Canterbury School of Law, Christchurch, 2008, 12. There are also some special needs of children, but they substantively vary per case. For example, the need for mental health care.

6 Howard Z, The little book of restorative justice, Good Books, New York, 2014, 37-38. Rossner M, 'Restorative justice and victims of crime: Directions and developments' in Walklate S, (ed) Handbook of victims and victimology, Routledge, 2017, 3 .
} 
reintegration and restoration must be realised within the community where the offence occurred, through diversion policies and devolution of decision-making powers. ${ }^{7}$ Diversion policies are the permissive laws, practices and policies that allow for the use of other justice mechanisms outside the formal justice system. ${ }^{8}$ They also cast power and recognition to these alternative practices and systems to generate and encourage sustainable and restorative outcomes. ${ }^{9}$ To this effect, it is the key to restorative justice. Nevertheless, there can be diversion without a restorative approach ${ }^{10}$ and this forms part of the main problems with the Nigerian system that this paper explores to remedy.

This paper evaluates the nature and design of the diversion policy for cases concerning young offenders in Nigeria. In Nigeria, a young offender is 'a child alleged to have committed an act which would constitute a criminal offence if [they] were an adult'. ${ }^{11}$ This means that a young offender is anyone below the age of majority, 18 years, who has offended the penal law. Regrettably, field studies conducted over 17 years show that the Nigerian juvenile justice system treats these young offenders in a manner that is inconsistent with their best interestthe best interest of the child principle. ${ }^{12}$ This satisfactory evidence stands as

Akintunde OW, 'Improving the criminal justice system in Nigeria through restorative justice: Lessons from Canada and New Zealand' Published LLM Thesis, Dalhousie University, Nova Scotia, 2018, 98. Schmid DJ, 'Restorative justice: A new paradigm for criminal justice policy' 34(1) Victoria University of Wellington Law Review, 2002, 92. Carruthers D, 'Restorative justice: Lessons from the past, pointers for the future' 20(1) Waikato Law Review, 2012, 5. The system is inclusive and flexible, thus, tends to be compatible to any cultural, ethnic, religious and political set-up or diversity because of the emphasis on the use of the natural institutions to drive the process. There are several scenarios where restorative justice can apply, but this paper focuses on the juvenile restorative justice framework. Setyorini EH and Utomo P, 'Restorative justice concept for children conflicting laws in children criminal justice system', 197.

8 UNICEF, Toolkit on diversion and alternatives to detention - $\underline{\text { https://www.unicef.org/tdad/ }}$ index $55660 . \mathrm{html}$ on 4 July 2020.

9 Van Ness D and Nolan P, 'Legislating for restorative justice' 10(53) Regent University Law Review, 1998, 57-58.

10 Setyorini EH and Utomo P, 'Restorative justice concept for children conflicting laws in children criminal justice system', 197.

11 The Child's Right Act (2003). Section 277 of this same Act defines a child as a person under the age of 18.

12 According to Nowak M, 'United Nations global study on children deprived of liberty', November 2019, 8 - 9- https://omnibook.com/view/e0623280-5656-42f8-9edf-5872f8f08562/page/1 on 24 July 2020, children as young as the age of eleven years are detained with adult offenders pending their trial. Some have already spent over two years in detention. Bella TT et al showed in their 2010 study that the police abuse two-thirds of the young offenders from their point of entry to the juvenile justice system. See Bella TT, Atilola $\mathrm{O}$ and Omigbodun O, 'Children within the juvenile justice system in Nigeria: Psychopathology and psychological needs' 8(1) Annals of Ibadan Post Graduate Medicine, 2010, 35. According to Abdulraheem-Mustapha MA, Child justice administration in Africa, Palgrave Macmillan, Switzerland, 2020, 172 and 188, the young offenders are tried by the same judges who sit for the adult cases in the adult courtrooms. Also, in page 9 and 183 the study

Vol. 6:1 (2021) p. 74 
the backbone for the evaluation this paper makes in order to understand what causes the continued mistreatment of young offenders in Nigeria. While there is sufficient literature advocating for the use of restorative justice in Nigeria, ${ }^{13}$ scholars seem to miss the major policy problem that limits the practice and impact of the same.

\section{ii. Highlighting the problem}

Under Nigeria's criminal justice framework, the Child's Right Act 2003 (CRA) is the principal legislation that provides for the treatment of young offenders ${ }^{14}$ and domesticates the UNCRC. ${ }^{15}$ Unfortunately, the CRA is inadequate as it fails to protect some principal interests of young offenders despite being the only statute that provides for a diversion policy. ${ }^{16}$ Even then, it is currently not applicable in the whole country because only 25 of the 36 states that form the Federal Republic of Nigeria have ratified it. ${ }^{17}$

finds that the police falsify the age of the young offenders to pass them through the formal justice system.

13 Generally, see: Ogwezzy M, Adebayo A and Kekere A, 'Restorative justice and non-custodial measures: Panacea to recidivism and prison congestion in Nigeria' 7 Nnamdi Aqikiwe Journal of International Law and Jurisprudence, 2016 ; Nnam M, 'Responding to the problem of prison overcrowding in Nigeria through restorative justice: A challenge to the traditional criminal justice system' 11(2) International Journal of Criminal Justice Sciences, 2016 ; Genger P, 'Combating corruption with African restorative justice tradition: suggested steps for Nigeria' 11(1) African Journal of Criminology and Justice Studies, 2018.

14 Section 204, The Child's Right Act (2003). This section provides that any child in conflict with the law shall be subjected 'only' to the child justice system and processes set out in the Act.

15 UN Committee on the Rights of the Child (CRC), Consideration of reports submitted by States parties under Article 44 of the Convention: Convention on the Rights of the Cbild: 3 rd and 4th periodic report of States, parties due in 2008 : Nigeria, 5 January 2010, CRC/C/NGA/3-4, 11. It is also worth noting that The 1999 Constitution of Nigeria does not explicitly speak to the treatment of young offenders but it recognises international law as part of the valid norms in the Nigerian legal landscape. International law, however, can only apply in the country if the Parliament domesticates it through an Act.

16 Section 208 and 209, The Child's Right Act (2003). There are some other laws within the system, for example The Criminal Code Act of Nigeria (Chapter 77 of 1990), fails to secure the best interest of the child in conflict with the law. The protection it guarantees children merely revolves around the prohibition of sexual and economic exploitation and the protection of life. More daunting, the Penal Code (Northern States) Federal Provisions Act (No. 25 of 1960) does not differentiate nor protect the child in any form.

17 Awofadeji S, 'Non-domestication of the Child Rights Act by 11 Northern states worries UNICEF, This Day, 24 November 2019 —https://www.thisdaylive.com/index.php/2019/11/24/nondomestication-of-the-child-rights-act-by-11-northern-states-worries-unicef/ on 22 July 2020. The function of child protection is under the concurrent list and some authors advocate for its transfer to the exclusive list to give it an automatic nationwide binding force. See Okpalaobi BN and Ekwueme CO, 'United Nations Convention on the Rights of a Child: Implementation of legal and administrative measures in Nigeria' 6 Nnamdi Azikiwe University Journal of International Law and Jurisprudence, 2015, 120 and 127. 
Of central interest to this paper is the diversion policy in section 208 and 209 of the CRA. Section 208 provides for the discretionary diversion of cases at any level of the formal justice system, post-arrest, during trial and sentencing, and post-sentencing. ${ }^{18}$ Section 209 allows for discretionary disposal of only 'nonserious cases' without resorting to the formal justice system and reserves the formal justice system for last resort. ${ }^{19}$

The problem with these sections is threefold. First, section 208 gives state officials, or anyone dealing with the case, the discretion to choose whether or not it is necessary to divert to a restorative justice mechanism. Related to this, section 209 provides for out-of-court disposal of 'only' non-serious cases. This means that when serious cases proceed to the formal process, they may not be amenable to restorative justice processes if the person dealing with the offence decides not to exercise the discretion to divert under section 208. The Beijing Rules recommend diversion even when a serious offence is committed, with due regard to the circumstances of the offence, for instance when the case involves a first offender. ${ }^{20}$ Second, the two sections allow the state officials to elect the restorative justice mechanism(s) that they wish to divert to. This means that there is no uniform practice of diversion and it affects the general coordination among the institutions tasked with the cases of young offenders. ${ }^{21}$ This contributes to more cases going to the mainstream since it is a system most conversant with the police, for example. ${ }^{22}$ Third, the sections are lax and inadequate and do not contain detailed yardsticks for measuring and monitoring the exercise of these discretionary powers for accountability purposes.

All of this shows that Nigeria's diversion policy is optional and lacks a restorative justice approach needed to protect the best interest of the child. This somewhat contradicts some scholarly opinions that the CRA is a standard legal document that is only challenged with insufficient resources, institutions, and political will for implementation. ${ }^{23}$ As this paper shows in detail, with the

18 Section 208, The Child's Right Act (2003). The section also provides for direction as the judge dealing with a case has the discretion to direct the parties to other justice frameworks like restorative justice.

19 Section 209, The Child's Right Act (2003).

20 Rule 11 (4), United Nations Standard Minimum Rules for the Administration of Juvenile Justice (The Beijing Rules), 29 November 1985, A/RES/40/33.

21 Abdulraheem-Mustapha MA, Child justice administration in Africa, 170 - 171.

22 Obidinma, A and Obidinma E, Challenges and prospects of the juvenile justice administration in South East Nigeria' 3 Nnamdi Azikiwe University Journal of International Law and Jurisprudence, $2012,85$.

23. Tajudeen I, 'Legal framework for the protection of child rights in Nigeria' 9(3) Agora International Journal of Juridical Sciences, 2015, 9 - 10. See Ajah B and Ugwuoke C, Juvenile justice administration and child prisoners in Nigeria' 13(2) International Journal of Criminal Justice Sciences, 2018, 444. The CRA may not be entirely bad, but it is inadequate to protect the young offenders within the juvenile

Vol. 6:1 (2021) p. 76 
Nigerian context in mind, the current optional diversion scheme is inadequate for the realisation of the best interest of the young offenders. This echoes Marriam Abdulraheem's assertion that the system for the young offenders in Nigeria is more of charity and not of rights or commitment. ${ }^{24}$

The central hypothesis of this paper is that taking away the discretionary powers under section 208 and 209 of the CRA can help improve the treatment of young offenders in Nigeria. To test this hypothesis, this paper is divided into six parts. Part I is the introduction and highlights the problem with the diversion scheme in Nigeria. Part II discusses restorative justice as the conceptual framework and the system within which the best interest of the child is better realised. This part shows the key role of a good diversion policy within the juvenile justice system to understand why diversion should be taken strictly. Part III discusses the international law instruments for restorative justice to show its wide acceptance and the international obligation that Nigeria has in the same light. It further assesses and discusses the flaws in the current practice in Nigeria to show the need for mandatory diversion. In Part IV, this paper studies New Zealand where there is a mandatory diversion scheme and a routine restorative justice practice for young offenders to show some emanating lessons that Nigeria can embrace. Part V makes some recommendations, and the paper concludes in Part VI. This research is offender-centred as it focuses on the mistreatment of young offenders to advocate for a committed restorative justice practice in Nigeria - a parallel justice system that is currently lacking.

\section{Restorative Justice and the Best Interest of the Child Principle}

\section{i. Understanding restorative justice}

Restorative justice is an empowering system that focuses on the harm done and how to prevent and heal it—as opposed to focusing on, and punishing, the offender. ${ }^{25}$ The harm could be immediate quantifiable injuries or unquantifiable ones like pain or suffering. ${ }^{26}$ Similarly, the victims could be specific individuals or a community. ${ }^{27}$ Notwithstanding, restorative justice is founded on the perception

justice system. This informs the dire need for a more focused legislation for this category of children from the point of view of this study.Abdulraheem-Mustapha MA, Child justice administration in Africa, 172.

24 Abdulraheem-Mustapha MA, Child justice administration in Africa, 73.

25 Van Ness D and Nolan P, 'Legislating for restorative justice', 53. Schmid DJ, 'Restorative justice: A new paradigm for criminal justice policy', 91.

26 Van Ness D and Nolan P, 'Legislating for restorative justice', 85.

27 Van Ness D and Nolan P, 'Legislating for restorative justice', 85. 
that an offence is primarily a break of human relationship that the entire community enjoys. ${ }^{28}$ So even when a direct individual is the victim of harm, the idea is that the entire community suffers its consequences and stands in danger.

Also, restorative justice recognises that humans are not born criminals; criminality has deeper diverse causes. ${ }^{29}$ Consequently, the outcomes of deliberations to rectify an offence are not wholly determined by the stateneither under its personnel nor formal structures. ${ }^{30}$ In some systems, they are determined by parties directly affected by the offence, namely, the victim, the offender, community members and perhaps state officials. ${ }^{31}$

Paul McCold simplifies restorative justice with a Venn diagram showing that it occurs at the intersection of three needs: victim reparation, offender responsibility and communities-of-care for reconciliation and reintegration. ${ }^{32} \mathrm{On}$ the one hand, McCold posits that any programme that fails to systematically and holistically achieve these three needs is not restorative. ${ }^{33}$ On the other hand, Van Ness and Karen Strong impliedly recognise that not every restorative justice process attains victim reparation, offender responsibility and communities-ofcare for reconciliation and reintegration, but a system that makes means for these elements available is restorative. ${ }^{34}$ This is true since it is a voluntary process and what the victim considers as justice to their case may be gravely inappropriate, malicious, an overreaction due to the effects of the harm or out of ignorance, and hence this desire could be disregarded. The offender may also elect to use the formal system, despite being provided with the option to divert. The question at this juncture is: does the system in Nigeria make available the means to realise these elements of restorative justice? The answer is in the negative since the diversion policy in Nigeria is a mirage; experiences have shown that it does not serve its designed purpose as a result of its laxity.

28 Luna E, 'Reason and emotion in justice' New Zealand Institute for Dispute Resolution, Victoria University of Wellington, Faculty of Law, Lecture Transcript, 5 July 2000- $\underline{\text { https://www.scoop. }}$ co.nz/stories/GE0007/S00014.htm on 3 May 2020.

29 Luna E, 'Reason and emotion in justice' New Zealand Institute for Dispute Resolution, Victoria University of Wellington, Faculty of Law, Lecture Transcript, 5 July 2000- $\underline{\text { https://www.scoop. }}$ co.nz/stories/GE0007/S00014.htm on 3 May 2020.

30 McCold, P, 'Toward a holistic vision of restorative juvenile justice: A reply to the maximalist model' 3(4) Contemporary Justice Reviem, 2000, 34. McCold terms such systems pseudo restorative program since they utilise the children's courts, state officials etc. They often fail to meet the true needs of restorative justice.

31 Schmid DJ, 'Restorative justice: A new paradigm for criminal justice policy', 127.

32 McCold, P, 'Toward a holistic vision of restorative juvenile justice', 34.

33 McCold, P, 'Toward a holistic vision of restorative juvenile justice', 33.

34 Van Ness D and Strong K, Restoring justice: An introduction to restorative justice, Routledge, 2014, 159.

Vol. 6:1 (2021) p. 78 
The United Nations Basic Principles on the use of Restorative Justice recognises that volition, like diversion, is at the heart of restorative justice. ${ }^{35}$ Where the court has not found the offender guilty, the offender has to freely admit the offence and the victim needs to freely explore restorative justice. Similarly, Donald Schmid rightly asserts that the restorative justice system must hold the offender accountable and this entails the offender 'recognising' the wrongfulness of their conduct, expressing remorse for any resulting injury, and taking actions to repair the damage done. ${ }^{36}$

Restorative justice mechanisms are geared towards achieving restorative outcomes through restorative processes. ${ }^{37} \mathrm{~A}$ restorative outcome is a product that champions the best interest of the young offender. ${ }^{38} \mathrm{~A}$ restorative process brings together all the parties that have a stake in an offence, such as family and community members and the state. ${ }^{39}$ They actively participate in the processes to reach a facilitated resolution. ${ }^{40}$ Examples of such processes and restorative justice models include victim-offender mediation or dialogue, peace-making cycles, and family or community conferencing models. ${ }^{41}$ The central quality they all share is that they are driven by diversion and volition of the parties. They are hence outside or parallel to the formal justice system. ${ }^{42}$ For instance, New Zealand uses a community and family group conferencing model known as the Family Group Conference (FGC). ${ }^{43}$ This is a conferencing model that brings together the victim, the offender, and the family members of both, the police officer, the social workers, a coordinator and a host of other stakeholders to have a proper dialogue concerning the causes and consequences of the offence and explore its appropriate remedies. ${ }^{44}$

35 UN Economic and Social Council, Resolutions and decisions adopted by the United Nations Economic and Social Council at its substantive session (1-26 July 2002), 13 August 2002, E/2002/INF/2/Add.2, 57, para 7.

36 Schmid DJ, 'Restorative justice: A new paradigm for criminal justice policy', 96.

37 United Nations Office on Drugs and Crime, Handbook on restorative justice programmes, United Nations, New York, 2006, 7.

38 United Nations Office on Drugs and Crime, Handbook on restorative justice programmes, 9 - 13. See also UN Economic and Social Council, Resolutions and decisions adopted by the United Nations Economic and Social Council at its substantive session, 56.

39 UN Economic and Social Council, Resolutions and decisions adopted by the United Nations Economic and Social Council at its substantive session, 56.

40 United Nations Office on Drugs and Crime, Handbook on restorative justice programmes, 7.

41 United Nations Office on Drugs and Crime, Handbook on restorative justice programmes, 14 - 15.

42 McCold, P, 'Toward a holistic vision of restorative juvenile justice, 34.

43 Carruthers D, 'Restorative justice: Lessons from the past, pointers for the future', 4

44 Umbreit M and Armour MP, 'Restorative justice dialogue: An essential guide for research and practice' Springer Publishing Company, New York, 2011, 143. 


\section{ii. Some benefits of restorative justice}

Restorative justice can be used for any type of dispute, regardless of who the dispute or offence concerns. ${ }^{45}$ However, this paper is only concerned with the juvenile restorative justice practice because of the best interest of the child principle that it advocates for. Moreover, the best systems practising restorative justice, like New Zealand, started with strict application to young offenders. New Zealand has a mandatory diversion policy for the practice of restorative justice for 'virtually all youth offender cases' and an optional policy for the adults who wish to explore it. ${ }^{40}$

This system is appraised for many reasons. First, a restorative justice process can be held anywhere including learning institutions, faith institutions and at homes. Second, the system is inclusive and flexible and thus, it can be compatible with any cultural, ethnic, religious and political set-up or diversity. ${ }^{47}$ This is because it is driven by informal key players. For example, in New Zealand, the process begins by reading out the particulars of the offence and giving the offender the chance to 'admit' or confess why they committed the offence. ${ }^{48}$ Then, the victim voluntarily explains the effects of the offence on them and the offender explains why the victim was victimised, shows remorse, and apologises. The families negotiate a plan and the record of the process is tendered to court for scrutiny and approval. ${ }^{49}$

Furthermore, the proponents of this system claim high success in offence management and crime detection and prevention. ${ }^{50}$ It is believed that people who go through this system are less likely to re-offend and more likely to be reintegrated into society. ${ }^{51}$ A study conducted by Jeffrey Bouffard and others shows that

45 United Nations Office on Drugs and Crime, Handbook on restorative justice programmes, 26.

46 Carruthers D, 'Restorative justice: Lessons from the past, pointers for the future', 5 and 7.

47 Akintunde OW, 'Improving the criminal justice system in Nigeria through restorative justice: Lessons from Canada and New Zealand' Published LLM Thesis, Dalhousie University, Nova Scotia, 2018, 98. Schmid J, 'Restorative justice: A new paradigm for criminal justice policy', 92.

48 Schmid DJ, 'Restorative justice: A new paradigm for criminal justice policy', $101-102$.

49 O'Driscoll S, 'Youth justice in New Zealand: A restorative justice approach to reduce youth offending', 136th international training course visiting experts' papers, Resource Material Series Number 75, 2008, 64 https://www.unafei.or.jp/publications/pdf/RS_No75/No75_10VE_O'Driscoll.pdf on 23 July 2020. Schmid DJ, 'Restorative justice: A new paradigm for criminal justice policy', 102.

50 Braithwaite J, 'Evidence for restorative justice' Special Issue, The Vermont Bar Journal, 2014. They include cost effective crime prevention, offender rehabilitation and reintegration, victim satisfaction etc.

51 Barton C, 'Theories of restorative justice' 2(1) Australian Journal of Professional and Applied Ethics, 2000, 3. Barton Charles explains the possibility of this in four ways: Reversal of moral disengagement: (re)engaging the offender at a moral psychological level with the consequences of their behaviour; 2. Social and moral development: aiding the moral and social development of the offender, so that

Vol. 6:1 (2021) p. 80 
young offenders who went through the formal justice system evidenced greater recidivism of 48.9 percent within an average period of 3.5 years. ${ }^{52}$ Whereas within the same average period, young offenders who were exposed to parallel justice systems presented the following percentages of recidivists:

i) Those who were subjected to minimal or no restorative justice evidenced 30.8 percent recidivism;

ii) Those who went through indirect mediation showed 27.3 percent recidivism;

iii) Those who were subjected to a restorative justice panel showed 24.2 percent recidivism; and

iv) Those who went through direct mediation revealed 33.5 percent recidivism. ${ }^{53}$

To drive this point home, Erik Luna argues that people commit offences mostly as a way of revolting against a system that they perceive to disrespect them or deny them certain rights. ${ }^{54}$ This aligns with Olayinka Atilola's assertion that in Nigeria, many 'young people are facing multiple social difficulties that might increase their recourse to crime and/or invoke their criminalization'. ${ }^{55}$ Therefore, by allowing young offenders to contribute to the resolution of their case in a setting that is comfortable to them and amid both the police officers and the other members of the society, they feel somewhat respected and valued. This makes restorative justice a more empowering system than the formal system where the young offender may be advised to keep silent while their advocates

they can learn and become wiser from the experience; 3. Emotional and moral psychological healing: aiding emotional and moral psychological healing from the trauma of the criminal incident through interaction between the parties and symbolic reparation; 4. Re-integrative shaming: tempering unequivocal disapproval of the wrongful behaviour (shaming) with expressions of respect and acceptance of the individual into their community (reintegration).

See also Waireri S, 'The role of restorative justice in the social reintegration of offenders in Kenya' Published LLB Thesis, Strathmore University, Nairobi, 2017, 1.

52 Bouffard J, Cooper M and Bergseth $\mathrm{K}$, 'The Effectiveness of various restorative justice interventions on recidivism outcomes among juvenile offenders' 15(4) Youth Violence and Juvenile Justice, 2017, 474. Dr Jeffrey Bouffard is a professor in the department of criminal justice and criminology and a research director at the Correctional Management Institute of Texas, Sam Houston State University.

53 Bouffard J, Cooper M and Bergseth $\mathrm{K}$, 'The Effectiveness of various restorative justice interventions on recidivism outcomes among juvenile offenders', 474.

54 Luna E, 'Reason and emotion in justice' New Zealand Institute for Dispute Resolution, Victoria University of Wellington, Faculty of Law, Lecture Transcript, 5 July 2000-https://www.scoop. co.nz/stories/GE0007/S00014.htm on 3 May 2020.

55 Atilola O, 'Juvenile/Youth justice management in Nigeria: Making a case for diversion programmes' 13(1) Youth Justice, 2013, 4. 
litigate for them. ${ }^{56}$ This formal practice somewhat disregards the need for the full participation of the child for their best interest. ${ }^{57}$ This also helps to show why a restorative justice model could have a better outcome.

\section{iii. The flaws of the formal justice system}

Restorative justice seems to stand out when compared to a purely formal justice system. For instance, Ian Marsh argues that the reforms from the formal justice system are somewhat ineffective.$^{58}$ In support, this paper argues that one of the reasons for this ineffectiveness is the denial of voluntary responsibilities which amplify people's civic nature. For example, it is not coercive when accused persons choose to participate in court to receive a reduced sentence. But it is coercive when the accused is ordered to participate as a condition of the sentence. ${ }^{59}$ Another example is that sanctions like community service are punitive when they are not closely connected to the harm done. ${ }^{60}$ Based on an aspect of coercion, such sanctions may be counter-effective or not effective at all.

Additionally, the problem with the formal system is that all the interested parties affected by an offence are reduced to just two - the state and the offender. Justice is thus distributed to the victim of the offence, the offender, and the larger society when the offender is punished or sentenced. ${ }^{61}$ This makes justice a winner-takes-it-all system, not a negotiated agreement, as Anne Skelton calls it. ${ }^{62}$ There is often no real question of what the victim considers to be justice but what the state, the winner, wants. ${ }^{63}$ This is not the ideal practice because

56 Luna E, 'Reason and emotion in justice' New Zealand Institute for Dispute Resolution, Victoria University of Wellington, Faculty of Law, Lecture Transcript, 5 July 2000-https://www.scoop. co.nz/stories/GE0007/S00014.htm on 3 May 2020.

57 UN Committee on the Rights of the Child (CRC), General comment No. 14 (2013) on the right of the child to have his or her best interests taken as a primary consideration (art. 3, para. 1), 29 May 2013, CRC/C/GC/14, 11, para 43.

58 Marsh I, Cochrane J and Melville G, Criminal Justice: An introduction to philosophies, theories and practice, Routledge, London, 2004, 4.

59 Van Ness D and Nolan P, 'Legislating for restorative justice', 83 - 84.

60 Van Ness D and Nolan P, 'Legislating for restorative justice', 87.

${ }^{61}$ Akintunde OW, 'Improving the criminal justice system in Nigeria through restorative justice: Lessons from Canada and New Zealand' Published LLM Thesis, Dalhousie University, Nova Scotia, 2018, 113.

62 Luna E, 'Reason and emotion in justice' New Zealand Institute for Dispute Resolution, Victoria University of Wellington, Faculty of Law, Lecture Transcript, 5 July 2000-https://www.scoop. co.nz/stories/GE0007/S00014.htm on 3 May 2020.Skelton A, 'Developing a juvenile justice system for South Africa: International instruments and restorative justice’ Acta Juridica, 1996, 193.

63 This does not mean that whatever the victim requests is what is just to the case as there is the need to balance the impact of the offence with the request of the offender.

Vol. 6:1 (2021) p. 82 
as Stephen O'Driscoll notes, children with criminal records are more likely to become recidivists. ${ }^{64}$ The opposite could be true, when a child escapes justice by way of acquittal through formal litigation, the child may likely re-offend believing that the justice system is flawed.

Furthermore, the formal justice system aims to repair reputations through adversarial means instead of healing the harms caused. This happens when a system encourages offenders to abscond responsibility by relying on the formal justice system to establish their guilt beyond reasonable doubts or getting their case dropped for a lack thereof. ${ }^{65}$

Such facts are not unique to young offenders but the impact could be felt more by them considering their vulnerability. This assertion could be valid since the state might reform but cannot reintegrate. Ideally, reintegration happens in the community of persons. ${ }^{66}$ By contrast, adult offenders may find it easier to pave their routes back into society than young offenders. Also, adult offenders might have better ways of coping with the effects of an offence. For instance, Bella T and others carried out a study in 2010 which found that two-thirds of children subjected to Nigeria's juvenile justice system develop psychological challenges and are abused from their point of contact (the police). ${ }^{67}$ Hence, it is inappropriate to 'continue' subjecting the fate of young offenders into the hands of the state officials to merely exercise their wide discretionary powers. There needs to be a mandatory diversion at the different levels of the juvenile justice system for the best interest of the child. This justifies why many international law instruments seek to promote the practice that takes young offenders outside the formal justice system to include more informal stakeholders.

${ }^{64}$ O' Driscoll S, 'Youth justice in New Zealand', 73. Although the reduction of recidivism is not the sole purpose of the restorative justice model, but it can come in between. The sole purpose centres on the entire best interest of the child and reparation of the harm.

65 Braithwaite J, 'Restorative justice and responsive regulation: The question of evidence', RegNet Research Paper No. 51, 38.

${ }_{66}$ Maruna S, 'Who owns resettlement? Towards restorative re-integration' 4(2) British Journal of Community Justice, 2006, 26.

${ }_{67}$ Bella TT, Atilola $\mathrm{O}$ and Omigbodun O, 'Children within the juvenile justice system in Nigeria', 35. This occurs despite the specialized unit that the Act tends to provide for the police. However, the author recognizes the need to hold the police accountable for their mistreatment of the young offenders. Similarly, there is also the need to properly train the police on how to best handle the young offenders. 


\section{The International Standards for Restorative Justice Practices}

\section{i. $\quad$ The international legal instruments}

Many international law instruments advocate for restorative justice, either directly or through principles. Nigeria has signed, ratified and domesticated some of these laws. Regardless of whether they apply to the Federal Republic of Nigeria or not, they are equally important to show why Nigeria needs stringent legal provisions to protect the best interest of young offenders. This paper chooses the UNCRC because it is currently the most robust global legal instrument on the rights of the child. ${ }^{68}$ The United Nations Standard Minimum Rules for the Administration of Juvenile Justice (the Beijing Rules) also show the basic rules that states must observe and integrate into their juvenile justice systems. ${ }^{69}$ Lastly, the United Nations Guidelines for the Prevention of Juvenile Delinquency (The Riyadh Guidelines) and the United Nations Standard Minimum Rules for Non-custodial Measures (The Tokyo Rules) are respectively used to show international approaches to child penal offence preventive systems and penalties for young offenders. ${ }^{70}$

This section shows the international standards and bases for restorative justice practice and the extent to which Nigeria's system falls below the expected threshold in theory.

\section{a. The UNCRC}

The UNCRC is among the international legal instruments that have imposed restorative justice measures such as rehabilitation, reconciliation, and reintegration on Nigeria. This is specifically regarding Article 3, which stresses that the best interest of the child shall always be the primary focus of every decision concerning the child. ${ }^{71}$ Similarly, the UNCRC has been proclaimed the most robust provision on the rights of the child. Koh Peters represents these rights with three Ps: the provision for the child, the protection of the child, and the participation of the child. ${ }^{72}$ The child is protected from danger, exploitation

68 The paper does not include the African Charter on the Rights and Welfare of the Child because it is similar to the UNCRC and the CRA appears to domesticate the two in Nigeria. See Okpalaobi BN and Ekwueme CO, 'United Nations Convention on the Rights of a Child', 120.

69 United Nations Standard Minimum Rules for the Administration of Juvenile Justice (The Beijing Rules), 29 November 1985, A/RES/40/33.

70 United Nations Guidelines for the Prevention of Juvenile Delinquency (The Riyadh Guidelines), 14 December 1990, A/RES/45/112; United Nations Standard Minimum Rules for Non-Custodial Measures (The Tokyo Rules), 2 April 1991, A/RES/45/110

71 Article 3, UN Convention on the Rights of the Child.

72 Peters J, 'How children are heard in child protective proceedings, in the United States and around the

Vol. 6:1 (2021) p. 84 
and abuse. ${ }^{73}$ The UNCRC makes this provision by stressing the importance of 'parenthood' and implores states to take measures to secure this relationship. ${ }^{74}$ Moreover, it stresses that the child should be provided with whatever is needed for their mental, physical and spiritual wellbeing. ${ }^{75}$ On participation, it states that the child has a participatory right in the matters that concern them. ${ }^{76}$

Furthermore, the UNCRC enjoins all the signatory states to take all appropriate legislative, administrative, social and educational measures to protect the child' ${ }^{77}$ Of great consideration is Article 40 of the UNCRC which centres on the treatment accorded to the young offenders. ${ }^{78}$ Article 40 provides that the law must ensure that a child offender is treated with the 'desirability of promoting the child's reintegration and the child's assuming a constructive role in society'. ${ }^{79}$ It also states that the rights of a young offender must be explained to them, preferably through their parents or legal guardians where appropriate. ${ }^{80}$ It further bars any form of delay and advocates for expeditious determination of the case concerning the young offender by a competent authority. Additionally, it encourages the authority in the case to take care of the varying special circumstances of the case of the young offender, like age, their situation and their parents or legal guardians. ${ }^{81}$ States are also encouraged to establish laws, procedures, authorities and institutions specifically applicable to children alleged of infringing penal law. Examples include the use of other forms of dispute resolution distinct from the court system..$^{82} \mathrm{~A}$ good legal system in this light must create a good diversionary institution for young offenders. ${ }^{83}$

\section{b. The Beijing Rules}

The rules largely focus on the principles and procedures that guide the treatment of young offenders. This document starts by advocating for the most

world in 2005: Survey findings, initial observations, and areas for further study' 6(966) Nevada Law Journal, 2006, 971.

73 Article 19, 32, 34, 36 and 39, UN Convention on the Rights of the Child.

74 Article 3 (2), UN Convention on the Rights of the Child.

75 Article 27, UN Convention on the Rights of the Child.

76 Article 12, 13 and 14, UN Convention on the Rights of the Child.

77 Article 4 and 19, UN Convention on the Rights of the Child.

78 Article 40, UN Convention on the Rights of the Child.

79 Article 40 (1), UN Convention on the Rights of the Child.

80 Article 40 (2) (b) (ii), UN Convention on the Rights of the Child. Appropriateness is measured using the best interest of the child.

81 Article 40 (2) (iii), UN Convention on the Rights of the Child.

82 Article 40 (3), UN Convention on the Rights of the Child.

83. Van Ness D and Nolan P, 'Legislating for restorative justice', 59. 
minimum intervention under the law and to promote the full mobilization 'of all possible resources, including the family, volunteers and other community groups, as well as schools and other community institutions, for the purpose of promoting the well-being of the juvenile..$^{84}$

Of great relevance to this study is Rule 6.2 which cautions every system that grants the use of discretion 'to ensure sufficient accountability at all stages and levels in the exercise of any such discretion'. ${ }^{85}$ Similarly, Rule 11 centres on diversion and cautions the states to obtain the consent of the young offender or their guardian before diverting any case. ${ }^{86}$ Also, to facilitate the discretionary disposition of cases, it calls upon states to make efforts to provide for community programmes. ${ }^{87}$ On the proceedings of cases, it emphasises the need to have the offender's full participation in an atmosphere of understanding and to allow for optimum free expression of interests. ${ }^{88}$

\section{c. The Tokyo Rules and the Riyadh Guidelines}

The Tokyo Rules aim to enhance 'greater community involvement in the management of criminal justice, specifically in the treatment of offenders, and to promote among offenders a sense of responsibility towards society' ${ }^{99}$ It tends to achieve this aim by proposing reduced custodial outcomes of juvenile justice systems. ${ }^{90}$ Rule 5 to 9 provide for alternative disposal of cases at any level of the justice system, pre-trial, trial and sentencing stage and post-sentencing stage. ${ }^{11}$

The Riyadh Guidelines ${ }^{92}$ concern the prevention of juvenile delinquency by prioritising the place of the family institution, the community and the educational institution and the mass media in this pursuit.

\footnotetext{
84 Rule 1.3, The United Nations Standard Minimum Rules for the Administration of Juvenile Justice (the Beijing Rules).

85 Rule 6.2, The United Nations Standard Minimum Rules for the Administration of Juvenile Justice (the Beijing Rules).

86 Rule 11.3, Rule 6.2, The United Nations Standard Minimum Rules for the Administration of Juvenile Justice (the Beijing Rules).

87 Rule 11.4, Rule 6.2, The United Nations Standard Minimum Rules for the Administration of Juvenile Justice (the Beijing Rules).

88 Rule 14.2, Rule 6.2, The United Nations Standard Minimum Rules for the Administration of Juvenile Justice (the Beijing Rules).

89 Rule 1.2, United Nations Standard Minimum Rules for Non-custodial Measures (The Tokyo Rules).

90 Rule 1.5, United Nations Standard Minimum Rules for Non-custodial Measures (The Tokyo Rules).

91 United Nations Standard Minimum Rules for Non-Custodial Measures (The Tokyo Rules).

92 United Nations Guidelines for the Prevention of Juvenile Delinquency (The Riyadh Guidelines).
}

Vol. 6:1 (2021) p. 86 


\section{ii. The underperformance of Nigeria}

The CRA meets some of the standards set out in the international law instruments above while falling short of other expectations. At the bare minimum, Nigeria is mandated to meet obligations spelt out in section 40 of the UNCRC for young offenders. This is because Nigeria assumed a position to observe these guidelines by way of assent and ratification of the convention.

The convention does not explicitly mention the use of restorative justice but it captures some core provisions that guide a restorative process such as the need for proper involvement of the young offender's parent or legal guardian, ${ }^{93}$ the use of the informal mechanisms for a speedy resolution of cases and the protection of the best interest of the child. It also emphasises the need for the young offender's inclusivity. Nigeria falls below the UNCRC standard for failing to expressly provide for voluntary participation of the child under the CRA. The CRA also fails to foster the speedy determination of cases through its silence on timelines.

Nigeria's system under the CRA falls below the standards under the Beijing rules on two grounds. First, section 208 and 209 which allow for diversion pays little attention to the consent and volition of the young offender either directly or through their parents or guardians. On the contrary, it emphasises the discretion of state officials. If anything, it allows the court to use the court system without necessarily obtaining consent from the parent or guardian of the young offender. ${ }^{94}$ Furthermore, the CRA is guilty of coercing measures on the offenders in two ways. The court is mandated to give orders when the offender is found to have committed the offence. ${ }^{95}$ Notwithstanding, the CRA disregards the need to ensure that such orders are direct responses to the offence since accountability is not about punishment but the offender's understanding of the impact of their offence and the steps to rectify the offence. ${ }^{96}$ Likewise, the court can order for the detention of the child 'where the child is found to have attempted to commit treason, murder, robbery or manslaughter, or wounded

93 It could be rightly argued that restorative justice may share this factor with the formal justice system. However, in Nigeria, without reservation the CRA empowers the court to dispose a case even when parents do not consent to it. Section 217(2), The Child's Right Act (2003).

94 Section 217(2), The Child's Right Act (2003). There is no debate on whether a child can give a valid consent in the Act because the Act provides for consent when it comes to adoption, child custody etc. but fails to provide for the consent of the young offender which is among the elements that restorative justice depends on to thrive.

95 Section 223, Child's Right Act (2003).

96 Howard Z, 'The little book of restorative justice', 33. 
another person with the intent to do grievous harm'. ${ }^{97}$ This form of punishment neglects the core principles of restorative justice and stands to be purely punitive.

Second, the CRA is silent on accountability mechanisms for the exercise of the discretionary powers that it grants. Although it cautions that only experts can exercise such discretion, evidence reveals that experts abuse this privilege. ${ }^{98}$ Hence, mere cautions are not enough to secure a committed and routine practice of diversion.

On the community involvement as guaranteed by some of the international law instruments, the CRA is not clear. It leaves it to state officials to discretionarily decide who is to be involved and to what extent they are to be involved.

Nigeria's underperformance is further evidenced in other ways. To illustrate, when a young offender is arrested in Nigeria, the police are often the first point of contact. After the arrest, young offenders are often tried and incarcerated. ${ }^{99}$ Scholars argue that the young offenders 'are remanded in prison custody indefinitely because the judicial officer is either totally ignorant of the procedure to be adopted or is confused about it'. ${ }^{100}$ Importantly, while all this is happening, the police often do not inform, for example, the young offender's parents, that their child is going through a criminal justice process. ${ }^{101}$ Moreover, when it comes to the hearing, the young offenders are tried in open courts by the same judges who adjudicate over adult cases. ${ }^{102}$ This goes against the common knowledge that young offenders are a special category of offenders that deserve specialised systems. ${ }^{103}$ Similarly, when the offender admits the offence, without reservations,

97 Section 222, Child's Right Act (2003). Iyabode Ogunniran argues that the CRA creates a bifurcation of offence where some cases are not amenable to the alternative systems. Hence, he argues that asides from the instances mentioned in section 222 of the CRA, every other offence should be deemed minor offences. See Ogunniran I, 'The lock and key phenomenon: Reforming the penal policy for child offenders in Nigeria' 10(1) Justice and Policy Journal, 2013, 18. This paper does not contend with that argument but finds that even the serious cases ought not be disposed of in court without due consideration to the restorative justice practices. See the discussion on New Zealand under Part IV. South East Nigeria' 3 (1) Nnamdi Azikiwe University Journal of International Law and Jurisprudence, 2012, 85. Abdulraheem-Mustapha MA, Child justice administration in Africa, 185 - 189. The challenge is that the police has traditionally been acquainted with the formal system. A tradition that needs strictness to break from.

101 Ajah B and Ugwuoke C, 'Juvenile justice administration and child prisoners in Nigeria', 445.

102 Abdulraheem-Mustapha MA, Child justice administration in Africa, 172 and 188.

103 Article 40 (3), UN Convention on the Rights of the Child; Luna E, 'Reason and emotion in justice' New Zealand Institute for Dispute Resolution, Victoria University of Wellington, Faculty of Law, Lecture

Vol. 6:1 (2021) p. 88 
the CRA allows the court to proceed to sentence a young offender. ${ }^{104}$ A proper restorative justice diversion mechanism emphasises the offender's admittance of the case as this paper shows.

In light of the flaws that Nigeria's diversion system has within the framework of restorative justice, this paper proceeds to discuss New Zealand where there is a committed practice of mandatory diversion for young offenders.

\section{Mandatory Diversion Policy in Action: Lessons from New Zealand}

Some scholars have pronounced New Zealand's restorative justice practice as a gift from New Zealand to the world. ${ }^{105}$ Restorative justice started in New Zealand through the Māori community who were displeased with how the fate of their children was left in the hands of state institutions and state officials and they wanted to be closely involved. ${ }^{106}$ Thus, they advocated for the inclusion of the Whānau, the family members, in matters involving young offenders. ${ }^{107}$ This led to the integration of dispute resolution mechanisms that have restorative principles that the Māori community practised before colonialism. ${ }^{108}$

This paper studies New Zealand for many reasons. Like Nigeria, New Zealand has ratified the UNCRC, ${ }^{109}$ and the ratification document guarantees a system widely referenced for its mandatory diversion that aids its restorative justice practice. ${ }^{110}$ New Zealand is a member of the commonwealth and practices the English common law like Nigeria. ${ }^{111}$ Hence, the possibility of realising restorative justice, at least, at the normative level in Nigeria since the formal

Transcript, 5 July 2000 -https://www.scoop.co.nz/stories/GE0007/S00014.htm on 3 January 2021. Erik Luna shows the history of the Juvenile justice systems and gives reasons for the varying historical attempts to differentiate the young offenders for the adult offenders in principle and in practice.

104 Section 217(6) and (8), The Child's Right Act (2003).

105 Ross R, 'Searching for the roots of conferencing' in Burford G and Hudson J (ed), Family Group Conferencing: New directions in community-centered child and family practice, Transaction Publishers, 2009, 5.

106 Consedine J, Restorative justice: Healing the effects of crime, 1995, 183.

107 Fulcher L, 'Cultural origins of the contemporary family group conference, 5 (4) Child Care in Practice, 1999, 328-339.

108 Consedine J, Restorative justice: Healing the effects of crime, 6.

109 New Zealand ratified on 6 April 1993. See-https://www.justice.govt.nz/justice-sector-policy/ constitutional-issues-and-human-rights/human-rights/international-human-rights/UNCRC/ on 2 January 2021.

110 For example, see Schmid DJ, 'Restorative justice: A new paradigm for criminal justice policy', 91.

111 O’ Driscoll S, 'Youth justice in New Zealand ', 55. 
systems of both countries have a similar colonial foundation. Additionally, New Zealand has robust legislation on the use of the restorative justice model which is supplemented by other laws and policies. ${ }^{112}$

However, there may be some limits. New Zealand is less populous and this might contribute to the effective implementation of policies and better utilisation of resources. Nevertheless, this is not a dissuading factor since Nigeria is devolved into different levels of government for the same purpose of efficiency and representation. New Zealand is also culturally different from Nigeria but this paper is about the mandatory use of diversion for young offenders, a focus that revolves around the legal provisions of the two countries on the protection of the best interest of the child.

\section{i. $\quad$ The legislative measures in New Zealand}

Besides ratifying the UNCRC, New Zealand has taken many legislative steps to decentralise the jurisdiction of the formal justice system over child offenders. A deviation from, and devolution of, the formal justice system as the custodian of primary jurisdiction of all cases concerning the young offender was made so as to concentrate some of it on the informal people. ${ }^{113}$ The country enacted the Children, Young Persons and their Families Act (CYPFA) in 1989 to institutionalise and empower restorative justice for young offenders. ${ }^{114}$ It is important to note the robustness of the CYPFA in protecting the principles set out in the UNCRC by including more principles that help to explain the best interest of the child principle.

Some of the general principles guiding the application of the CYPFA are set out in sections 5 and 13. For example, the CYPFA demands that the family and community members of the child must be at the centre of every decision concerning the child. ${ }^{115}$ This follows the understanding that family members are the ones who can best protect the child. ${ }^{116}$ Similarly, consideration must be given to the wishes of the child, ${ }^{117}$ and the implementation of any decision must

112 Children, Young Persons, and Their Families Act (New Zealand). Some of these other laws are the Sentencing Act of 2002, Victims' Rights Act of 2002, Parole Act of 2002, the Corrections Act of 2004, the 2004 Ministry of Justice Principles of Best Practice, and the May 2002 Guidelines for Restorative Justice Processes in Prisons.

113 Carruthers D, 'Restorative justice: Lessons from the past, pointers for the future', 5.

114 The Children, Young Persons, and Their Families Act (New Zealand). Carruthers D, 'Restorative justice: Lessons from the past, pointers for the future', $3-5$.

115 Section 5(a), The Children, Young Persons, and Their Families Act (New Zealand).

116 Section 13(b), The Children, Young Persons, and Their Families Act (New Zealand).

117 Section 5(d), The Children, Young Persons, and Their Families Act (New Zealand).

Vol. 6:1 (2021) p. 90 
be within the 'timeframe appropriate to the child's or young person's sense of time'. ${ }^{118}$ This principle helps to foster the speedy determination of cases involving a young offender. It creates a system where expedition is measured based on the child's sense of it and the child's growth.

\section{ii. Mandatory diversion policy for restorative justice in New Zealand}

Mandatory diversion underscores the juvenile justice system in New Zealand for nearly all cases involving a young offender. ${ }^{119}$ The diversion policy allows for the use of alternative systems at any time in the justice system or before entry into the justice system. ${ }^{120}$ This is similar to the CRA. However, the main difference is on the post-arrest stage. ${ }^{121}$ In New Zealand, state officials do not have the discretion to choose whether or not to divert cases as they must divert to an FGC when the offender pleads guilty or has been found guilty by a competent authority. ${ }^{122} \mathrm{~A}$ court is restricted from disposing of a case until an FGC is held and they are mandated to consider the outcome of the FGC in their orders. ${ }^{123}$ Added to this factor is the full voluntariness of the parties to the case.

The FGC is an informal gathering involving the Police Officer in charge of a case, the family members and friends of the young offender, ${ }^{124}$ the offender, the victim, social workers, youth and lay advocates, a Care and Protection Coordinator and any other person with a relevant reason to attend. ${ }^{125}$ Whatever the families decide is given legal effect and binds everyone, save for the extent to which it contravenes any of the general guiding principles. ${ }^{126}$

118 Section 5(f), The Children, Young Persons, and Their Families Act (New Zealand).

119 Carruthers D, 'Restorative justice: Lessons from the past, pointers for the future', 5 and 7.

120 Van Ness D and Nolan P, 'Legislating for restorative justice', 70 - 75.

121 The chaos in Nigeria's system is more notable at the post arrest stage. This is where the abuse of discretion, mistreatment of the young offenders and disregard of restorative justice is vivid. This includes the imprisonment of children and their trials in adult courts or by adult judges.

122 'How restorative justice works'-https://www.justice.govt.nz/courts/criminal/charged-with-acrime/how-restorative-justice-works/\#process on 28 December 2020.

123 Section 281, The Children, Young Persons, and Their Families Act (New Zealand).

124 As noted by Luna, even colleagues like Rugby players can attend. Luna E, 'Reason and emotion in justice' New Zealand Institute for Dispute Resolution, Victoria University of Wellington, Faculty of Law, Lecture Transcript, 5 July 2000 - https://www.scoop.co.nz/stories/GE0007/S00014.htm on 3 May 2020.

125 Section 22 and 251, The Children, Young Persons, and Their Families Act (New Zealand).

126 Section 250 (c), 267 and 268, The Children, Young Persons, and Their Families Act (New Zealand). Although, as the reader will note under this section, this does not diminish the informal nature of the process since the courts are limited from entirely relinquishing the recommendations on the grounds of such a contravention. The courts can order for the reconvention of the FGCs.

Vol. 6:1 (2021) p. 91 
Chiefly, the offender is present to actively participate in the correction of their wrong. The victim is also present to help determine what they define as justice in their case and to understand or seek an explanation regarding their victimization. ${ }^{127}$ Both are 'on parallel journeys of dealing with the crushing impact of shame'. ${ }^{128}$ For one, the shame of harming and for the other, the shame of being harmed.

Although restorative justice mechanisms can be made mandatory, the process is voluntary, and any involved party may decide not to attend the process. For instance, the victim may decide to abscond. However, after considering the need for the victim's presence and whether the focus is primarily on the offender and not on the victim of the case, then the process may proceed. ${ }^{129}$ Alternatively, the victims could participate through a 'victim's surrogate'. ${ }^{130}$ Needless to say, the victims' attendance and contribution make the process more effective but if a party fails to attend, the existence of the programme is still a sign of respect to them. ${ }^{131}$ This concurs with Ness' and Strong's conclusion that any system that makes provision for the realisation of restorative justice can be termed restorative, ${ }^{132}$ even if it fails to realise the desired restorative justice outcomes.

The police officer is present to help create order. For example, to prevent the further victimization of the victim and to prevent any form of mob justice that may arise against the offender during the process. ${ }^{133}$ They also get the opportunity to develop crime prevention and detection strategies due to the community focus geared towards solving the root cause of a particular offence. ${ }^{134}$ Schmid reports that two-thirds of gang activities have been eliminated over the years through policing insights derived from restorative processes. ${ }^{135}$ The presence of the police

127 This follows all that is explained in part II of this paper.

128 Marshall C, Compassionate justice: An interdisciplinary dialogue with two gospel parables on law, crime and restorative justice, Cascade Books, Oregon, 2012, 231.

129 Van Ness D and Nolan P, 'Legislating for restorative justice', 80.

130 Rossner M, 'Restorative justice and victims of crime: Directions and developments', 4.

131 O' Driscoll S, YYouth justice in New Zealand, 65. Schmid DJ, 'Restorative justice: A new paradigm for criminal justice policy', 102; Luna E, 'Reason and emotion in justice' New Zealand Institute for Dispute Resolution, Victoria University of Wellington, Faculty of Law, Lecture Transcript, 5 July 2000—https://www.scoop.co.nz/stories/GE0007/S00014.htm on 3 May 2020. Erik Luna shows that people offend when they feel threatened or disrespected; hence punishment may not necessarily deter through threats but can outdo itself.

132 Van Ness D and Strong K, Restoring justice: An introduction to restorative justice, 159.

133 O' Driscoll S, 'Youth justice in New Zealand', 66; Schmid DJ, 'Restorative justice: A new paradigm for criminal justice policy', 132; The Children, Young Persons, and Their Families Act (New Zealand).

134 Schmid DJ, 'Restorative justice: A new paradigm for criminal justice policy', 92.

135 Schmid DJ, 'Restorative justice: A new paradigm for criminal justice policy', 92 - 93. Schmid, however, cautions that the restorative justice is not a panacea nor can it supplant the mainstream but

Vol. 6:1 (2021) p. 92 
in this discourse also increases the confidence the people have in them; due to the friendly environment the process creates, it likewise changes the people's perception of the police from bad to good. ${ }^{136}$ Overall, the police possess a better sense of ownership in the FGC because the formal justice system seemingly limits their participation with procedural routines. ${ }^{137}$

The family of the offender and the victim help drive the process, censure the offence, and craft and monitor healing plans. These are the sole parties allowed to sit and decide the fate of the offender as every other member is isolated once this stage is arrived at. ${ }^{138}$ O'Driscoll notes that the name 'family group' means that it goes beyond just the parents of the parties, to include as many family members as possible-even the extended family members. ${ }^{139}$ Braithwaite rightly notes that due to the principal role of family members and friends, the offender feels that they have been treated as a person worthy of the trust of these relatives. ${ }^{140}$ This alone is a great step towards the reintegration and rehabilitation of the offender.

The Youth Advocates mainly attend to ensure that the process conforms to legislative provisions. ${ }^{141}$ They ensure this by certifying that all the rights of the young offender are well realised. ${ }^{142}$ The Lay Advocates attend in order to standardise the process according to the culture. ${ }^{143}$ As a result, one may argue that restorative justice is a holistic system that integrates the customary justice system and the formal justice system to offer the best possible solution to the complexities of a case. The social workers attend for purposes of FGC outcome implementation. Whatever the families agree upon may be further facilitated and monitored by the social workers to ensure accountability and exercise initiative on the side of the offender.

Every party is instrumental to this restorative justice model and any of the cited parties who could not attend the FGC must give a convincing reason for their failure to do so. ${ }^{144}$ Similarly, any unlisted person who is not needed for any

can be a tool that has proven to be very effective.

136 Schmid DJ, 'Restorative justice: A new paradigm for criminal justice policy', 127.

137 Nicholl C, 'Community policing, community justice, and restorative justice: Exploring the links for the delivery of a balanced approach to public safety, U.S. Department of Justice, Office of Community Oriented Policing Services, Washington DC, 1999, 149 - 152.

138 Section 251(4) and 22(2), The Children, Young Persons, and Their Families Act (New Zealand).

139 O' Driscoll S, YYouth justice in New Zealand', 66 - 67.

140 Braithwaite J, Restorative justice and responsive regulation, 36.

141 Schmid DJ, 'Restorative justice: A new paradigm for criminal justice policy', 132 - 133.

142 O' Driscoll S, 'Youth justice in New Zealand', 68 - 69. This includes the right to be silent, to be heard etc.

143 O' Driscoll S, 'Youth justice in New Zealand', 68 -69.

144 Section 24 and 254, The Children, Young Persons, and Their Families Act (New Zealand).

Vol. 6:1 (2021) p. 93 
information or advice but who wants to attend the FGC must give a convincing reason to secure their attendance. ${ }^{145}$

The general procedure for the FGC is sealed under section 26 and 256 that allow the FGCs to regulate themselves within the confines of the general principles. ${ }^{146}$ Hence, the testimony by Erik Luna that no conference looks the same as any other. ${ }^{147}$ However, in a bid to ensure faster delivery of justice, strict guidelines are stipulated as to time. For instance, the Youth Justice Co-ordinator is expected to organise an FGC within 21 days after the report of a case is received. ${ }^{48}$ This is important since it will be very detrimental to have the case of a young offender delayed until they grow into full adults with such a heavy burden on their shoulders. Delaying the case of a young offender has the potential of distorting their physical and spiritual growth and development; it can slow down their academic performance and excellence. Worse still, it can create confusion when it comes to the question of what amounts to an appropriate penalty as the person dealing with the case might be conflicted as to whether to punish the offender as an adult, or as a young offender which is the status they occupied when they committed the offence.

However, it is not every case that is diverted in New Zealand. This occurs in four scenarios. The first is when the offender admits the offence outright and elects to be tried in court. ${ }^{149}$ Second, where the FGC is sidestepped when the Coordinator and the Family and Community Members believe that having an FGC will not yield good results. ${ }^{150}$ This is probably informed by the offender's general character, previous or subsequent offences. ${ }^{151}$ Nevertheless, the CYPFA removes all forms of biases by outlining some considerable factors that inform whether an FGC will be fruitful or otherwise. It provides that before such a conclusion, the coordinator and the community members must consider the

\footnotetext{
145 Section 255 (2), The Children, Young Persons, and Their Families Act (New Zealand).

146 Section 26 and 256, The Children, Young Persons, and Their Families Act (New Zealand).

147 Luna E, 'Reason and emotion in justice' New Zealand Institute for Dispute Resolution, Victoria

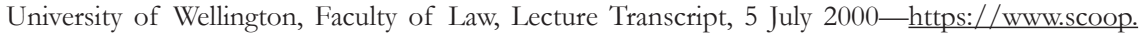
co.nz/stories/GE0007/S00014.htm on 3 May 2020.

148 Section 249(1), The Children, Young Persons, and Their Families Act (New Zealand).

149 Section 276, The Children, Young Persons, and Their Families Act (New Zealand).

150 Section 248(1)(b), The Children, Young Persons, and Their Families Act (New Zealand).

151 Section 248(2) and (3), The Children, Young Persons, and Their Families Act (New Zealand). The two subsections only provide for instances where the FGC is not needed based on an offence subsequently committed by a young offender pending the completion of an FGC over another offence they previously committed. It also provides for no FGC when the young offender commits another offence after six weeks of completing an FGC. The author amalgamates the provisions and interprets it as questions regarding tendency to offend and general character.
}

Vol. 6:1 (2021) p. 94 
offender's response to the offence, the seriousness of the offence and the place of the offender in the offence. ${ }^{152}$

Third, where a young offender is directly brought to court in cases of murder, manslaughter or a traffic offence not punishable by imprisonment. ${ }^{153}$ The author posits that part of the reason for this provision is because murder and manslaughter cases are highly emotive, extremely grave and the victim is not alive to attend the FGC, and hence the 'preliminary hearing' should be in the court. ${ }^{154}$ For traffic offences not punishable by imprisonment, the punishments are fairly straightforward as the driving license of the young offender could be temporarily or permanently withdrawn or they may be fined. It becomes complex when the traffic offence is punishable by imprisonment as the court must consider the personal and family circumstances of the offender. The fourth scenario is when it is in the public interest to have the case determined under the formal system and the CYPFA outlines some criteria for the determination of public interest. ${ }^{155}$

Notwithstanding the waiver under any of the four scenarios, the court is empowered to either proceed to adjudicate on the case or, if it believes that there is a need to have one, revert it for a FGC. ${ }^{156}$

The proceedings of the FGC are barred from being published and the executive is mandated to provide any assistance needed to facilitate the process, financial or otherwise. ${ }^{157}$ Additionally, the outcome of the process is monitored, and the FGC may reconvene to review the plans previously made or adopt specific ways of implementing them if there are challenges with implementation. ${ }^{158}$

\section{iii. The role of the court and the synergy between the parallel systems in New Zealand}

In many cases, the court occupies a secondary role. Inasmuch as the FGC may be sidestepped in a few instances, the CYPFA bars the Court from making

\footnotetext{
152 Section 248(4) and (5), The Children, Young Persons, and Their Families Act (New Zealand).

153 Section 246 and 272, The Children, Young Persons, and Their Families Act (New Zealand). Whether the offender pleads guilty or not, they are brought to court for preliminary hearings.

154 272(4), The Children, Young Persons, and Their Families Act (New Zealand).

155 Section 245, The Children, Young Persons, and Their Families Act (New Zealand). The public interest could be determined using the seriousness of the offence, the result of an FGC held previously, the response of the offender to the offence other factors.

156 Section 281A, The Children, Young Persons, and Their Families Act (New Zealand).

157 Section 268, 271, The Children, Young Persons, and Their Families Act (New Zealand).

158 Section 270, The Children, Young Persons, and Their Families Act (New Zealand).
} 
orders unless an FGC is conducted. ${ }^{159}$ This means that even for the most serious offences, after the preliminary hearing, the court must direct the coordinator to hold an FGC. Moreover, if the court disagrees with any recommendation of the FGC on grounds that it defeats any of the guiding principles, it cannot substitute such a recommendation with its own but instead it orders the FGC to reconvene. ${ }^{160}$ This paper argues that this is a stride forward to substantiate the relevance of the FGC and to liberate it from serving as an ordinary procedural gateway to the formal justice system or subjugating it to the mainstream.

When adjudicating a case, the CYPFA sets out the conditions the court must consider. ${ }^{161}$ These include the nature of the case and the young person's involvement, and the relevant personal history, social circumstances and personal characteristics of the young person. Additionally, the response of the victim and the offender to the offence as well as their families.

The court is restricted from imposing fines on the children who cannot pay them within twelve months. ${ }^{162}$ Moreover, only those who probably have petty savings or can save and would be able to clear the fine within the stipulated time are fined. ${ }^{163}$ This is to further realise a restorative justice practice that demands a connection between an offence and the penalty for the offence and fosters the responsibility of the offender in the rectification mechanism. Further, in the worst-case scenario, the court may place the fine on the parent or guardian or even sentence the offender if they are fifteen years of age or above. ${ }^{164}$ As O'Driscoll correctly summarises, the courts act as a backstop and a filter because they are the last resort and they help to decide what amounts to a satisfactory recommendation. ${ }^{165}$

The justice system founded by the CYPFA in New Zealand is exhaustive in defining and protecting the best interest of the child through diversionary mechanisms. The category of cases to be automatically diverted, how, when, and where to divert them are spelt out in law and commendably realised through practice. The system in New Zealand adequately provides for restorative justice and perfectly incorporates it into the formal juvenile justice system to drive it to

\footnotetext{
159 Section 281(1), The Children, Young Persons, and Their Families Act (New Zealand).

160 Section 281(2), The Children, Young Persons, and Their Families Act (New Zealand).

161 Section 284, The Children, Young Persons, and Their Families Act (New Zealand).

162 Section 285 (3), The Children, Young Persons, and Their Families Act (New Zealand).

163 O' Driscoll S, 'Youth justice in New Zealand', 72.

164 Section 283, The Children, Young Persons, and Their Families Act (New Zealand).

165 O’ Driscoll S, 'Youth justice in New Zealand', 70.
}

Vol. 6:1 (2021) p. 96 
fruition. ${ }^{166}$ Furthermore, several principles of restorative justice are clear in New Zealand's system such as the involvement of parents and family, consideration of the special circumstances of young offenders and some guiding steps for this consideration. Additionally, the use of community programmes is clear. Hence it is more compliant with international standards. This is unlike Nigeria where the law grants wide discretionary powers and emphasises the formal juvenile justice system with little attention to the fate of restorative justice.

\section{Paving the Way Forward for an Effective Diversion Policy and Juvenile Restorative Justice in Nigeria}

The CRA was enacted to remedy the abuse of diversion and the inadequacy of the laws preceding it. ${ }^{167}$ This is also established in Nigeria's submission to the CRC in 1998, where it is noted that the then active legislation with regard to the administration of juvenile justice and institutionalization of children does not appear to conform to the principle and provisions of the Convention'. ${ }^{168}$ Though the CRA starts by calling on the attention of stakeholders to the necessity of protecting the best interest of the child, ${ }^{169}$ it is currently inadequate to achieve restorative justice for young offenders in Nigeria.

The CRC, while considering a Nigerian submission in 2010, primarily recommended that Nigeria encourages diversion for young offenders. ${ }^{170}$ Likewise, this paper recommends separate legislation that furthers the CRA by repealing some of its sections that are inadequate to cater for restorative justice. Nigeria needs separate legislation focused on restorative justice for young offenders since scholars have opined that a repackaged system is unlikely to be restorative and may fail. ${ }^{171}$ This legislation must grant a mandatory diversion for the following three reasons informed by lessons from New Zealand and some guiding questions recognised internationally. ${ }^{172}$

\footnotetext{
166 Pfander S, 'Evaluating New Zealand's restorative promise: The impact of legislative design on the practice of restorative justice' 15 (1) New Zealand Journal of Social Sciences Online, 2020, 171.

167 Abdulraheem-Mustapha MA, 'Child justice administration in the Nigerian Child's Right Act: Lessons from South Africa' 16 (2) African Human Rights Law Journal, 2016, 435, 437.

168 Committee on the Rights of the Child, Consideration of reports submitted by states parties under Article 44 of the Convention; second periodic reports of states parties due in 1998; Nigeria, CRC/C/70/Add.24, 17 September 2004, 6, para 5.

169 Section 1, Child's Right Act (2003).

170 UN Committee on the Rights of the Child, Consideration of Reports Submitted by States Parties under Article 44 of the Convention, Concluding observations: Nigeria, CRC/C/NGA/CO/3-4, 2010, Para 91(h).

171 Daly K, 'Restorative justice: The real story’ 4 (1) Punishment and Society, 2002, 6.

172 United Nations Office on Drugs and Crime, Handbook on restorative justice programmes, 53.
} 
First, the goal of the diversion policy in Nigeria should be to provide guidance and structure for restorative justice programmes. ${ }^{173}$ This is vital for the establishment and promotion of a favourable culture for the use of restorative justice among state officials and community members. ${ }^{174}$ Empirical studies validate the conclusion that there is a lack of coordination between the different agencies tasked with the treatment of young offenders in Nigeria. ${ }^{175}$ A police officer may be well acquainted with the court system; however, when it comes to diversion, such an official may not know how to involve the family members of the offender, the victim, the offender and other stakeholders in order to resolve the case. The officer may also be confused as to the impact and acceptance of the outcome of such a process by the legal system. ${ }^{176}$ Likewise, it would be difficult for the police to interact with other relevant institutions to secure timely and adequate resources to pursue diversionary mechanisms. ${ }^{177}$

Second, the diversion policy must secure the protection of offenders' and victims' rights while participating in restorative programmes. ${ }^{178}$ The CRC notes that a host of practices in Nigeria, mostly cultural, go against the best interest of the child principle. ${ }^{179}$ Thus, it urged Nigeria to explicitly make policies, legislations and practices to protect the child's best interest. ${ }^{180}$ Consequently, there is a possibility that the offender may not receive fair treatment and needs to be protected by a robust law dealing with young offenders outside the formal justice system. This violation could take the form of mob justice and stigmatisation of the offender. The victim of the offence may further be victimised by the offender and this could rejuvenate the victim's trauma. Therefore, a legal system like Nigeria's is expected to have clear guidelines on how to protect these parties.

173 United Nations Office on Drugs and Crime, Handbook on restorative justice programmes, 53.

174 United Nations, Basic Principles on the Use of Restorative Justice Programmes in Criminal Matters, 2000, para 20.

175 Abdulraheem-Mustapha MA, Cbild justice administration in Africa, 170 - 171.

176 Obidinma, A and Obidinma E, Challenges and prospects of the juvenile justice administration in South East Nigeria', 85.

177 Abdulraheem-Mustapha MA, Cbild justice administration in Africa, 240.

178 United Nations Office on Drugs and Crime, Handbook on restorative justice programmes, 53.

179 UN Committee on the Rights of the Child, Consideration of Reports Submitted by States Parties under Article 44 of the Convention, Concluding observations: Nigeria, CRC/C/NGA/CO/3-4, 2010, Para 30.

180 UN Committee on the Rights of the Child, Consideration of Reports Submitted by States Parties under Article 44 of the Convention, Concluding observations: Nigeria, CRC/C/NGA/CO/3-4, 2010, Para 31. An example of this is that the UNCRC, as domesticated via the CRA, is not applicable in some states. It is reported that 11 states are yet to ratify the CRA. They mostly include the Northern states which, among other reasons, conceive some of the provisions of the CRA to contradict a few tenets of the Islamic faith and tradition. The states that are yet to adopt the CRA are still operating under the legal regimes instituted by the colonialists.

Vol. 6:1 (2021) p. 98 
Third, the diversion policy must be geared towards the establishment of guiding principles and the mechanisms for monitoring the general adherence to those guiding principles. ${ }^{181}$ This helps to regulate and inform the exercise of any discretion that the CRA provides for.

Nevertheless, scholars level grave criticisms against excessive legislation of restorative justice mechanisms since this breeds government dominance instead of creating a parallel justice system. ${ }^{182}$ This follows Luna, who notes that restorative justice is an inherently flexible process but tends to follow a fairly standard pattern. ${ }^{183}$ David O'Mahony and others express that attitudinal resistance can hinder restorative justice initiatives and so produce a major gap in the theory and the practice of justice. ${ }^{184}$ O'Mahony further warns that 'the potential for this gap to expand is clearly exacerbated where decision-makers are given maximum scope for manoeuvre'. ${ }^{185}$ As a result, restorative justice demands that the proposed legislation aims for the following core elements:

i) To provide a specific restorative justice mechanism similar to the FGC or any other well-defined model in Nigeria while avoiding a blind transplant of systems. This paper suggests that, in the meantime, an offender-centred mechanism could be the most appropriate to vindicate mistreatment of young offenders.

ii) To clearly transfer power to these informal processes and make diversion mandatory for all cases as an alternative to the formal trial, before resorting to formal trial or before final disposal within the formal system. This paper takes the stance that even if the CRA currently guarantees out-of-court disposal of only minor offences under section 209 (1), the serious offences listed under section 222 merit restorative disposal. Therefore, the law must make it mandatory for the consideration of restorative justice before any case is concluded, except where it is gravely impracticable like the instances in New

\footnotetext{
181 United Nations Office on Drugs and Crime, Handbook on restorative justice programmes, 53.

182 Masters G, 'What happens when restorative justice is encouraged, enabled and/or guided by legislation?' in Zehr $\mathrm{H}$ and Toews B (eds), 'Critical issues in restorative justice, Criminal Justice Press, New York, 2004, 22.

183 Luna E, 'Reason and emotion in justice' New Zealand Institute for Dispute Resolution, Victoria University of Wellington, Faculty of Law, Lecture Transcript, 5 July 2000- $\underline{\text { https://www.scoop. }}$ co.nz/stories/GE0007/S00014.htm on 3 May 2020.

184 O’Mahony D, Doak J and Clamp K, 'The politics of youth justice reform in post-conflict societies: Mainstreaming restorative justice in Northern Ireland and South Africa' 63(2) Northern Ireland Legal Quarterly, 2012, 286.

185 O’Mahony D, Doak J and Clamp K, 'The politics of youth justice reform in post-conflict societies', 286.
} 
Zealand. ${ }^{186}$ By doing so, the discretionary powers are shifted to serve the varying circumstances that may exist within the restorative justice process but not to be 'loosely' exercised to decide whether or not to divert a case. This, according to the author, is the right strategy for exercising discretion to maintain the flexibility of restorative justice and avoid overregulation. The need to define the limits of the exercise of this discretion must be at the core.

iii) To provide a more defined and complementary role between the Nigerian courts and the parallel informal justice system. This helps to engineer a system that mandates the court to consider restorative justice processes and outcomes carefully and reasonably. ${ }^{187}$

iv) To secure free consent and full voluntariness of the young offenders. The CRA currently misses this point as it only looks at the discretion of state official to elect how to handle a case. The consent of offenders contributes to the success of restorative justice by focusing on the offender's full responsibility.

v) To set general principles and mandatory steps for every restorative justice process and allow them to regulate themselves internally within the confines of the general principles. For example, it must set out how the rights of the young offender are to be explained and protected. It must set out the maximum period within which a restorative justice process must commence to foster expedition of the process. For example, in New Zealand, this is twenty-one days. ${ }^{188}$

vi) To set out the steps for safeguarding the rights of the parties outside the formal justice system for security. Also, it must outline how to manage the records of the informal proceedings to retain privacy.

vii) To set out the requirements and training guidelines for those who administer the child justice system in the formal and informal spheres. This is due to Carruthers' emphasis on the need for specialist inputs and experience since restorative justice demands professionalism and mastery of processes. ${ }^{189}$ Hence, the need for more training on the use of restorative justice and diversion. This goes a long way to secure awareness and aid in the implementation of the proposed legislation.

\footnotetext{
186 See the discussion in the Part IV of this paper.

187 Carruthers D, 'Restorative justice: Lessons from the past, pointers for the future', 11.

188 Section 249(1), The Children, Young Persons, and Their Families Act (New Zealand).

189 Carruthers D, 'Restorative justice: Lessons from the past, pointers for the future', 17.
}

Vol. 6:1 (2021) p. 100 
To make this new policy framework effective, this paper sides with Okpalaobi and Ekwueme who advocate for the transfer of child protection roles from the concurrent list to the exclusive list to secure a nationwide practice of restorative justice. ${ }^{190}$ These recommendations may face some funding challenges and sociopolitical tensions. However, with time, political goodwill and commitment, it will overcome these impediments. The efforts to overcome the current challenges are worthwhile because in the words of Carruthers when referring to the value of restorative justice, 'notwithstanding the complexity of this area of work, there is overwhelming evidence of the value that it can yield when appropriately implemented, resourced and managed'. ${ }^{191}$

\section{Conclusion}

This paper examines the diversion policy for young offenders in Nigeria and finds that it lacks restorative justice and remains inadequate to realise it. Instead, it places the restorative justice framework in a hostile position by granting wide discretionary powers to state officials who drive the formal justice system. Discretion has its advantages. Nevertheless, it is a tool that demands carefulness since a discretionary diversion policy is subject to abuse, and the absence of mechanisms within the CRA to check on the exercise of these powers worsens the situation.

The author examined the practice in New Zealand to make a few recommendations that revolve around the provision of a mandatory diversion for the protection of the best interest of the children in conflict with the law. It is hoped that this research will create a new dawn for mistreated young offenders in Nigeria. Legislation might not completely and instantly solve the current hostile state of restorative justice for the young offenders in Nigeria, but it is a huge step towards it. If there is an intention to legislate a practice or system, then the corresponding legislation should be able to actualize the purpose of the intended practice or system. This is an important point that the CRA has missed.

To further realise juvenile restorative justice in Nigeria, this paper calls upon future researchers to look into a specific restorative justice model or mechanism that can properly function in Nigeria, bearing in mind the socio-political and economic differences. This paper also invites researchers to survey ways of funding the restorative justice mechanism and training and empowering those that drive it.

\footnotetext{
190 Okpalaobi BN and Ekwueme CO, 'United Nations Convention on the Rights of a Child', 120 and 127.

191 Carruthers D, 'Restorative justice: Lessons from the past, pointers for the future', 21.
} 